DOI https://doi.org/10.30525/978-9934-26-075-9-10

\title{
ДІАГНОСТИЧНІ ТА ЛІКУВАЛЬНІ АСПЕКТИ ХРОНІЧНОГО ТАЗОВОГО БОЛЮ У ЖІНОК 3 ХРОНІЧНИМИ ЗАПАЛЬНИМИ ПРОЦЕСАМИ ВНУТРІШНІХ СТАТЕВИХ ОРГАНІВ НА ТЛІ ВАРИКОЗНОГО РОЗШИРЕННЯ ВЕН МАЛОГО ТАЗА
}

\author{
Дрогомирецька Н. В. \\ кандидат медичних наук, \\ асистент кафедри акушерства та гінекології імені І. Д. Ланового \\ Івано-Франківський національний медичний університет \\ м. Івано-Франківськ, Украӥна
}

Серед численних проявів хронічних запальних процесів внутрішніх статевих органів (ХЗПВСО) особливе місце належить хронічному тазовому болю (ХТБ), який більшість дослідників вважають основним симптомом. ХТБ $є$ не лише медичною, але й соціальною проблемою, оскільки, зважаючи на тривалість, має негативні наслідки у вигляді психоемоційних порушень, зниження розумової та фізичної діяльності, впливу на якість життя [1, с. 66]. Особливої уваги вимагають стани, коли хронічний больовий синдром у ділянці малого таза зумовлений коморбідною патологією, що може мати спільні патофізіологічні механізми патогенезу та потенціювати розвиток одне одного [2, с. 23].

Метою дослідження була оптимізація стандартних підходів корекції ХТБ при ХЗПВСО у жінок з варикозним розширенням вен малого таза (ВРВМТ).

На етапі формування груп були відібрані 120 осіб репродуктивного віку з ХТБ і ХЗПВСО у анамнезі, які надалі підлягали проспективному дослідженню та були розподілені на дві групи: першу складали $68((56,7 \pm 4,5) \%)$ пацієнток з ХЗПВСО на тлі ВРВМТ, другу - 52 $((43,3 \pm 4,5) \%)$ з ХЗПВСО без ВРВМТ. До групи контролю увійшли 30 практично здорових жінок. Критеріями включення до груп вважали: вік жінки від 18 до 45 років, наявність в анамнезі епізодів загострень запальних захворювань органів малого таза, синдром ХТБ, ехографічні й ендоскопічні ознаки ВРВМТ. До ехографічних і доплерометричних ознак відносили наступні: підтверджена ультразвуковим дослідженням (УЗД) дилатація більше 5 мм у діаметрі будь-якого з основних венозних колекторів малого таза (яєчникових, маткових, аркуатних вен), позитивна проба Вальсальви, зниження пікової систолічної швидкості кровотоку в руслі маткових вен нижче 6 см/с. 3 метою включення в дослідження 42 
жінок 3 ХТБ використовували: візуально-аналогову шкалу (ВАШ), опитувальник болю Мак-Гілла, коротку оцінку болю. Для статистичної обробки матеріалу були застосовані комп'ютерні програми на основі Microsoft Office Excel з використанням ліцензованих пакетів статистичного аналізу Microsoft Excel i Statistica 7.0.

Згідно з класифікацією варикозу вен малого таза (Волкова А.С. та співавт., 2000), залежно від локалізації венозної ектазії та діаметра вен I ступінь зустрічався в $21((30,9 \pm 5,6) \%)$, II - $23((33,8 \pm 5,7) \%)$, III - $24((35,3 \pm 5,8) \%)$ випадках [3, с. 57].

Проведений аналіз скарг продемонстрував тривалий больовий анамнез у пацієнток першої групи: больовий синдром понад 3 роки в 1,5 раза частіше мали особи з ВРВМТ (66,2\%), хоча в другій групі їх відсоток був не менш вагомим (46,2\%). Оцінка інтенсивності болю за ВАШ, опитувальником Мак-Гілла, коротка оцінка болю показали значнішу частку вираженого больового синдрому порівняно 3 другою групою (в 2,5 раза; $\mathrm{p}<0,05)$, а також залежність інтенсивності болю від ступеня дилатації вен малого таза. При III ступені дилатації відсоток жінок $з$ вираженим болем був достовірно вищим порівняно з I ступенем у 2,0 раза, при II - 1,7 (p<0,05). Були встановлені паралелі між відсотком помірного (51,9 \%) болю в пацієнток другої групи та жінок першої групи з II ступенем дилатації (52,2 \%). Відповідно до опитувальника болю МакГілла, в осіб першої групи з II і III ступенями дилатації вен практично в усіх опрацьованих анкетах відзначалася багатогранна характеристика больового синдрому: ниючий, тягнучий біль - $43((91,5 \pm 4,1) \%)$, нерідко 3 почуттям втоми, тривоги, іноді нудоти - 53 ((77,9 95,0$) \%)$, біль-страждання - $12((17,6 \pm 4,6) \%)$, біль постійного характеру - $63((92,6 \pm 3,2) \%)$, іррадіацією в пряму кишку, поперекову ділянку, зовнішні статеві органи та промежину - більшої половини. Водночас при опитуванні жінок другої групи вказані характеристики відмічалися в половині випадків.

Величина показників, як-от ранговий індекс болю (РІБ), індекс кількості вибраних дескрипторів (ІКВД), сенсорний та афективний ІКВД, сила болю, в осіб першої групи залежала від ступеня дилатації варикозно розширених вен. Слід зазначити, що ці ж показники в пацієнток другої групи практично співпадали 3 даними першої групи 3 I ступенем дилатації варикозно розширених вен.

Зміни інтенсивності болю протягом доби серед жінок другої групи та першої з I ступенем дилатації варикозно розширених вен і за показником мінімального рівня болю в осіб з ІІ ступенем дилатації знаходилися практично на одному рівні. 
Усі пацієнтки обох обстежуваних груп отримували діосмінвмісний флеботропний препарат з групи біофлавоноїдів по 1 таблетці (500 мг) 2 рази на день у безперервному режимі та донатор оксиду азоту L-аргініну аспартат по 5 мл 3 рази на день per os курсами по 14 днів кожного місяця протягом шести місяців.

Після завершення запропонованого курсу лікування жінки обох груп відзначали значне зменшення суб'єктивних проявів, часто з повним зникненням больового синдрому, а також значне покращення загального стану та статевої функції. Ці показники були кращими у хворих другої групи й осіб першої групи з I ступенем дилатації варикозних вен малого таза.

3 отриманих результатів видно, що за даними ВАШ інтенсивність болю в жінок першої групи 3 I ступенем дилатації варикозних вен зменшилася на 2,52 балів, II - 1,41, III - 1,26; у пацієнток другої групи на 2,29 балів.

Після проведеного лікування за результатами опитувальника МакГілла в жінок першої групи з I та II ступенями дилатації варикозних вен особливо знижувалися наступні показники: РІБ на 2,26; 2,89 балів відповідно; ІКВД на 2,35; 2,30 балів; сенсорний ІКВД на 2,28; 2,14 балів (табл. 1).

Таблиця 1

Характеристика больового синдрому за опитувальником Мак-Гілла в обстежуваних жінок, $M \pm m$

\begin{tabular}{|c|c|c|c|c|}
\hline \multirow{2}{*}{ Показники } & \multicolumn{2}{|c|}{$\begin{array}{c}\text { ХЗПВСО+ВРВМТ з різним } \\
\text { ступенем дилатації вен } \\
\text { (n=68) (I - 21; II - 23; III - 24) }\end{array}$} & \multicolumn{2}{|c|}{ ХЗПВСО (n=52) } \\
\cline { 2 - 5 } & до лікування & $\begin{array}{c}\text { після } \\
\text { лікування }\end{array}$ & $\begin{array}{c}\text { до } \\
\text { лікування }\end{array}$ & $\begin{array}{c}\text { після } \\
\text { лікування }\end{array}$ \\
\hline $\mathbf{1}$ & $\mathbf{2}$ & $\mathbf{3}$ & $\mathbf{4}$ & $\mathbf{5}$ \\
\hline & I- & & & \\
РІБ & $(10,12 \pm 0,61)$ & $7,86 \pm 0,54^{*}$ & & $7,32 \pm 0,65^{* *}$ \\
& II - & $10,72 \pm 0,72^{*}$ & $9,95 \pm 0,53$ & \\
& $(13,61 \pm 0,61)$ & $12,24 \pm 0,76^{*}$ & & \\
& III - & & & \\
& $(15,64 \pm 0,93)$ & & & $4,15 \pm 0,38^{* *}$ \\
& I- & & & \\
\hline \multirow{4}{*}{ ІКВД } & $(7,53 \pm 0,34)$ & $5,18 \pm 0,21^{*}$ & & \\
& II - & $6,32 \pm 0,24^{*}$ & $7,12 \pm 0,35$ & \\
& $(8,62 \pm 0,26)$ & $6,87 \pm 0,30^{*}$ & & \\
& III - & & & \\
& $(8,74 \pm 0,37)$ & &
\end{tabular}


Продовження таблиці 1

\begin{tabular}{|c|c|c|c|c|}
\hline 1 & 2 & 3 & 4 & 5 \\
\hline $\begin{array}{c}\text { Сенсорний } \\
\text { ІКВД }\end{array}$ & $\begin{array}{c}\mathrm{I}- \\
(5,21 \pm 0,22) \\
\mathrm{II}- \\
(5,32 \pm 0,11) \\
\mathrm{III}- \\
(5,38 \pm 0,17)\end{array}$ & $\begin{array}{l}2,93 \pm 0,28^{*} \\
3,18 \pm 0,36^{*} \\
4,32 \pm 0,19^{*}\end{array}$ & $4,82 \pm 0,44$ & $2,54 \pm 0,31^{* * *}$ \\
\hline $\begin{array}{c}\text { Афективний } \\
\text { ІКВД }\end{array}$ & $\begin{array}{c}\mathrm{I}- \\
(2,31 \pm 0,16) \\
\mathrm{II}- \\
(3,30 \pm 0,15) \\
\mathrm{III}- \\
(3,36 \pm 0,20)\end{array}$ & $\begin{array}{c}1,72 \pm 0,12 \\
2,31 \pm 0,16^{*} \\
2,64 \pm 0,16^{*}\end{array}$ & $2,56 \pm 0,18$ & $1,23 \pm 0,18^{* *}$ \\
\hline Сила болю & $\begin{array}{c}\mathrm{I}- \\
(2,31 \pm 0,18) \\
\mathrm{II}- \\
(2,89 \pm 0,16) \\
\mathrm{III}- \\
(3,12 \pm 0,10)\end{array}$ & $\begin{array}{l}1,76 \pm 0,12^{*} \\
1,58 \pm 0,21^{*} \\
1,71 \pm 0,63^{*}\end{array}$ & $2,24 \pm 0,16$ & $1,17 \pm 0,12^{* *}$ \\
\hline
\end{tabular}

Примітка.

* - перша група до та після лікування $-\mathrm{p}<0,05$;

** - друга група до та після лікування - $<<0,05$.

Афективний ІКВД зменшувався менш показово (0,59; 0,$99 ; 0,72$ бала), що може свідчити про психоемоційний стан жінок з даною патологією. У пацієнток другої групи РІБ знизився на 2,63 балів; ІКВД - 2,97; сенсорний ІКВД - 2,28; афективний ІКВД - 1,33; сила болю - 1,17.

За результатами чотирискладової ВАШ показники, як-от біль на момент опитування, середній і мінімальний рівні болю, максимальний рівень болю після шести місяців лікування, в жінок другої групи зменшилися в середньому на 2,7 балів, першої групи з I і II ступенями дилатації варикозних вен - 2,6. В осіб з III ступенем дилатації різниця показників була неістотною та статистично недостовірною (p>0,05).

Отже, результати проведеного дослідження свідчать про існуючу резистентність до стандартних лікувальних програм і вказують на необхідність пошуку нових методів лікувального впливу в даної категорії пацієнток. Призначене жінкам досліджуваних груп патогенетично обгрунтоване лікування довело статистично достовірний позитивний клінічний результат, що виявлявся зменшенням інтенсивності болю за результатами ВАШ й опитувальників Мак-Гілла, короткої оцінки болю. 


\title{
Література:
}

1. Ночвіна О. А. Патогенетичні аспекти формування синдрому хронічного тазового болю у жінок репродуктивного віку. Wschodnioeuropejskie Czasopismo Naukowe. 2016. № 7, Ч. 1. C. 65-71.

2. The relationship between pelvic vein incompetence and chronic pelvic pain in women: systematic reviews of diagnosis and treatment effectiveness / R. Champaneria et al. Health Technology Assessment. 2016. Vol. 20, N 5. P. 1-108.

3. Волков А. Е. Эхосемиотика варикозного расширения вен малого таза. Эхография. 2000. Т. 1, № 1. С. 55-59.

DOI https://doi.org/10.30525/978-9934-26-075-9-11

\section{CHANGES IN THE CHARACTERISTICS OF THE GALLBLADDER IN PATIENTS WITH CHRONIC CHOLECYSTITIS AND COPD}

\author{
Dudka T. V. \\ Candidate of Medical Sciences, \\ Associate Professor at the Department of Internal Medicine, \\ Clinical Pharmacology and Occupational Diseases \\ Bukovinian State Medical University \\ Dudka I. V. \\ Candidate of Medical Sciences, \\ Associate Professor at the Department of Internal Medicine, \\ Clinical Pharmacology and Occupational Diseases \\ Bukovinian State Medical University \\ Pavlyuk V. O. \\ Deputy Head of the Department of Medical Assistance to the Population \\ Chernivtsi Regional State Administration Health Department \\ Chernivtsi, Ukraine
}

Different authors [2, p. 698] describe the development of gastric ulcer, gastric and duodenal erosions, chronic gastritis, duodenitis, reflux esophagitis and sliding hiatal hernia, duodenogastric reflux, changes in the liver, inflammation of the biliary tract and pancreas in the patients with chronic inflammatory diseases of the lungs and bronchi [4, p. 323]. Chronic acalculous cholecystitis (CAC) combined with chronic obstructive pulmonary disease 46 